\title{
Monetary Policy Shocks to Commodity Prices: Evidence from Pakistan
}

\author{
Farhan Ahmed ${ }^{1}$, Mushtaq Memon ${ }^{2}$, Raza $\mathrm{Ali}^{3}$
}

\begin{abstract}
Monetary policy is always a dynamic attribute on commodity prices in the economy. This article examines the empirical relationship between monetary policy and commodity price by employing a vector autoregression (VAR) Model to show its response in the case of Pakistan. In this paper, the research philosophy is employed based on Positivism with Deductive approach to recognizing the response of monetary policy shocks on commodity price. Recently, low-interest rates and excessive liquidity play a dynamic role in affecting the prices of the commodities market. Furthermore, the impact of monetary policy rate show significant result and seems to be huge in the economy of Pakistan massively. Besides, there is a stable relationship between monetary policy instrument and commodity prices even though the current financial crisis.
\end{abstract}

Keywords: monetary policy, commodity prices, developing economy, vector auto-regression (VAR)

\begin{abstract}
Abstrak
Kebijakan moneter selalu sebagai atribut dinamis pada harga komoditas dalam perekonomian. Artikel ini membahas hubungan empiris antara kebijakan moneter dan harga komoditas dengan menggunakan Model vektor-korelasi otomatis (VAR) untuk menunjukkan tanggapannya dalam kasus Pakistan. Dalam tulisan ini, filosofi penelitian digunakan berdasarkan Positivisme dengan pendekatan Deduktif untuk mengenali respon guncangan kebijakan moneter terhadap harga komoditas. Saat ini, suku bunga rendah dan likuiditas berlebihan memainkan peran dinamis dalam mempengaruhi harga pasar komoditas. Selain itu, dampak dari tingkat kebijakan moneter menunjukkan hasil yang signifikan dan tampaknya sangat besar dalam perekonomian Pakistan secara besar-besaran. Selain itu, ada hubungan yang sangat kuat antara instrumen kebijakan moneter dan harga komoditas meskipun krisis keuangan saat ini.
\end{abstract}

Kata Kunci: kebijakan moneter, harga komoditas, ekonomi berkembang, vector auto-regression (VAR)

\section{How to Cite:}

Ahmed, F., Memon, M., \& Ali, R. (2019). Monetary Policy Shocks to Commodity Prices: Evidence from Pakistan. Signifikan: Jurnal Ilmu Ekonomi. Vol. 8 (1): 37 - 50. doi: http://dx.doi.org/10.15408/sjie.v8i1.7012. 


\section{Introduction}

It is obvious that monetary policy is always driving force for commodity price globally and it is so important to examine the relationship between monetary policy and commodity price basket. Various studies responses on going to monetary policy to commodity price fluctuations (Gelos \& Ustugova, 2017; Hove et al., 2015). It is a serious concern to experts regarding monetary policy to commodity price for an extended period. However economists are finding the different role of speculators and demand, supply growth and other factors shock this commodity price boost and monetary policy does not receive as much attention.

Monetary policy leads to getting a long-lasting impact on commodity price in a country that has high food share in the spending basket and it is less tightly inflation as expected. Despite the healthy economic expansion of the previous year, the country economy is in progress with control. There is much growth in this year compared to the previous year than expected, and it is remarkable for the economy of the country. Apart from it, there is a recent slowdown in private sectors' consumption, and utilization that is owed to lower agriculture earning and debt of consumers and household could be detained, and one more component is a willingness to save. In the meantime, ambiguity about worldwide demand might have dragged personal investment, particularly in the export-oriented sector.

Sometimes the impact of monetary policy shocks to commodity price created inflation that is unpredicted and even not constant and unlikely to be controlled by economists and policymakers. The central bank is to establish the credibility to set better of setting and announcing the monetary policy in the shape of headline inflation, which is preferable in the economy rather than follows others. In this regards; Inflation is a complex issue and can create a gap in global output in different countries of the world. However, there is one critical factor that must include that is volatility of the nominal exchange rate.

Many authors also explore the effect of globalization on domestic price in the market. Pain et al. (2006) iscovered that import prices have a direct relation with inflation and the role of Organization for Economic Co-operation and Development (OECD) has a substantial impact on consumer price inflation. They highlighted one more point that stability in globalization, lesser inflation lead to enhancing the commodity prices and eventually to boost inflation because many counties have a lower cost of production and are usually more intensive for commodities. Wynne \& Kersting (2007) employ the connection between globalization and inflation. They discover a negative relationship having a long-term impact of inflation on various countries in the world. They add more to define that the overseas production gap creates inflation in a country like the United States.

Frankel (2006), Hammoudeh et al. (2015), Scrimgeour (2015) proved that expansionary monetary decision making and thin policy rate has a direct impact on high commodity prices (inflation). They recommend that the new strategy might have been optimistic for commodity manufactures and pessimistic for consumers. However, new strategies of study integrate current common public policies and findings are confirmed to explain the effects of the policies. Cody \& Mills (1991) assured that the impact of inflation would stress on 
commodity price in monetary policy criteria. Laxton \& Pesenti (2003) build an economic model in which they examine to stabilize features of various monetary policy systems under different shocks. They add further to explain that conventional Taylor rules do not perform better than inflation-forecast based rules and stabilization of inconsistency in output in the economy.

Parrado et al. (2004) employ a DSGE model in which he explains that the monetary policy and exchange rate can have differences in macroeconomic instability and welfare in the economy. In addition to domestic inflation, targeting yields present better results than CPI targeting ever since to stabilize inflation, real exchange rate, and the output gap. Anzuini et al. (2013) conclude that expansionary monetary policy shocks in the United States drive up the broad commodity price index and all of its components. Lovcha \& Perez-Laborda (2018) onclude that the long memory properties of inflation remain stable across the usual sample splits in the literature.

Gali \& Monacelli (2005) suggest a small open model in which to implicate the macroeconomics of CPI forecasting inflation, properties, domestic inflation targeting, and exchange rate objective. They also suggest that when establishments are in order; yield of targeting inflation to be stable outcome better than exchange rate targeting and CPI in response to output gap and inflation. Devereux et al. (2006) study a small open economy model in which there is an alternative monetary policy shock to terms of trade and foreign interest rate to the Asian economies. They invested in a study that non-tradable inflation is not better than CPI inflation targeting due to having a target in stabilization output. On the other hand, in order to stabilize the economy, it seems that CPI inflation has the expense of high fluctuation of exchange rate. They also add that financial obstacles have an external shock but not possible to alter the ranking of rules and regulations in monetary policy. As welfare analysis is a concern, they found that non-tradable inflation targeting executes better than exchange rate and CPI.

In the financial world, banks are legally needed to hold claims against central authority and banks create deposits and loans from that, the role of central authority is to control over the supply of claims against it. Therefore, it said that monetary policy is a powerful tool, which affects a country's economy, for either good or ill.

Pindyck \& Rotemberg (1993) state that commodity prices go simultaneously and the impact of current macroeconomics that surprises and evaluates the result against the standard competitive model of price development of commodity markets. They also have a dispute over the financial speculator who provides a possible outcome for their result. At the end of the result, the corresponding ups and downs of the process in different commodity market after the period 2006.

According to Garner (1985) put an argument that commodity prices play the central role in the market in order to get balance State Bank is to be supposed not target commodity price because it is complicated to control by them. Lapp (1990) formed a model in which it depicted that inadequate information and rational expectations determine agricultural commodities price. In the year 1951 to 1985 , monetary policy has not played a significant 
role in changing agricultural prices. Lapp (1990) instigated only one year that has a positive effect of unanticipated money growth on prices.

Based on several previous studies, it has found that there are some contradictions related to the relationship between monetary policy shocks and commodity prices. This study will examine the relationship between monetary policy and commodity price by employing a vector auto-correlation in Pakistan. So, this study will make a significant contribution in seeing how the effects of the shock due to changes in monetary policy on commodity prices.

\section{Methods}

In order to get a significant result of the research paper is to employ a Vector Auto Regression Model (VAR). The Vector Auto Regression Model is useful in time series data and more analytical, organized and consistent with examining the effects of dependent variables for quantitative research. The collection of data is based on monthly from January 2008 to August 2016 and had received from Pakistan Bureau of Statistics Department. The requirement of data is according to a VAR environment as literature suggested. To check the response of monetary policy shocks to commodity price has reciprocal retort of endogenous variance. There is also an estimation of the Impulse response function in the graphical representation and to see shocks in percentage by employing the Variance Decomposition test.

To predict and anticipate the data, VAR is run to check normality in the model, and different variables can also be the part of text appraisal. First, the impact on monetary policy to commodity price has to be vision the financial market to predict and evaluate in a way that variation of prices in crude oil, land and agriculture crop is put forward in Pakistani market and useful for economists and participates. Second, the well-organized information about the provisional and certain disparity of the monetary policy to commodity price that will be helpful for the market.

Below given are the model expressed in form of the equation.

$$
\begin{aligned}
& \mathrm{MPR}_{\mathrm{t}}=\alpha_{1}+\beta_{1} \mathrm{GT}_{\mathrm{t}}+\beta_{2} \mathrm{HSD}_{\mathrm{t}}+\beta_{3} \mathrm{KO}_{\mathrm{t}}+\beta_{4} \mathrm{PS}_{\mathrm{t}}+\beta_{5} \mathrm{RB}_{\mathrm{t}}+\beta_{6} \mathrm{RBB}_{\mathrm{t}}+\beta_{7} \mathrm{RBS}_{\mathrm{t}}+\beta_{8} \mathrm{WHEAT}_{\mathrm{t}}+\epsilon_{\mathrm{t}} \\
& \mathrm{GT}_{\mathrm{t}}=\alpha_{2}+\beta_{1} \mathrm{MPR}_{\mathrm{t}}+\beta_{2} \mathrm{HSD}_{\mathrm{t}}+\beta_{3} \mathrm{KO}_{\mathrm{t}}+\beta_{4} \mathrm{PS}_{\mathrm{t}}+\beta_{5} \mathrm{RB}_{\mathrm{t}}+\beta_{6} \mathrm{RBB}_{\mathrm{t}}+\beta_{7} \mathrm{RBSt}+\beta_{8} \mathrm{WHEAT}_{\mathrm{t}}+\epsilon_{\mathrm{t}} \\
& \mathrm{HSD}_{\mathrm{t}}=\alpha_{3}+\beta_{1} \mathrm{MPR}_{\mathrm{t}}+\beta_{2} \mathrm{HSD}_{\mathrm{t}}+\beta_{3} \mathrm{KO}_{\mathrm{t}}+\beta_{4} \mathrm{PS}_{\mathrm{t}}+\beta_{5} \mathrm{RB}_{\mathrm{t}}+\beta_{6} \mathrm{RBB}_{\mathrm{t}}+\beta_{7} \mathrm{RBSt}+\beta_{8} \mathrm{WHEAT}_{\mathrm{t}}+\epsilon_{\mathrm{t}} \\
& \mathrm{KO}_{\mathrm{t}}=\alpha_{4}+\beta_{1} \mathrm{MPR}_{\mathrm{t}}+\beta_{2} \mathrm{HSD}_{\mathrm{t}}+\beta_{3} \mathrm{KO}_{\mathrm{t}}+\beta_{4} \mathrm{PS}_{\mathrm{t}}+\beta_{5} \mathrm{RB}_{\mathrm{t}}+\beta_{6} \mathrm{RBB}_{\mathrm{t}}+\beta_{7} \mathrm{RBSt}+\beta_{8} \mathrm{WHEAT}_{\mathrm{t}}+\epsilon_{\mathrm{t}} \\
& \mathrm{PS}_{\mathrm{t}}=\alpha_{5}+\beta_{1} \mathrm{MPR}_{\mathrm{t}}+\beta_{2} \mathrm{HSD}_{\mathrm{t}}+\beta_{3} \mathrm{KO}_{\mathrm{t}}+\beta_{4} \mathrm{PS}_{\mathrm{t}}+\beta_{5} \mathrm{RB}_{\mathrm{t}}+\beta_{6} \mathrm{RBB}_{\mathrm{t}}+\beta_{7} \mathrm{RBSt}+\beta_{8} \mathrm{WHEAT}_{\mathrm{t}}+\epsilon_{\mathrm{t}} \\
& \mathrm{RB}_{\mathrm{t}}=\alpha_{6}+\beta_{1} \mathrm{MPR}_{\mathrm{t}}+\beta_{2} \mathrm{HSD}_{\mathrm{t}}+\beta_{3} \mathrm{KO}_{\mathrm{t}}+\beta_{4} \mathrm{PS}_{\mathrm{t}}+\beta_{5} \mathrm{RB}_{\mathrm{t}}+\beta_{6} \mathrm{RBB}_{\mathrm{t}}+\beta_{7} \mathrm{RBSt}+\beta_{8} \mathrm{WHEAT}_{\mathrm{t}}+\epsilon_{\mathrm{t}} \\
& \mathrm{RBB}_{\mathrm{t}}=\alpha_{7}+\beta_{1} \mathrm{MPR}_{\mathrm{t}}+\beta_{2} \mathrm{HSD}_{\mathrm{t}}+\beta_{3} \mathrm{KO}_{\mathrm{t}}+\beta_{4} \mathrm{PS}_{\mathrm{t}}+\beta_{5} \mathrm{RB}_{\mathrm{t}}+\beta_{6} \mathrm{RBB}_{\mathrm{t}}+\beta_{7} \mathrm{RBSt}+\beta_{8} \mathrm{WHEAT}_{\mathrm{t}}+\epsilon_{\mathrm{t}} \\
& \mathrm{RBS}_{\mathrm{t}}=\alpha_{8}+\beta_{1} \mathrm{MPR}_{\mathrm{t}}+\beta_{2} \mathrm{HSD}_{\mathrm{t}}+\beta_{3} \mathrm{KO}_{\mathrm{t}}+\beta_{4} \mathrm{PS}_{\mathrm{t}}+\beta_{5} \mathrm{RB}_{\mathrm{t}}+\beta_{6} \mathrm{RBB}_{\mathrm{t}}+\beta_{7} \mathrm{RBSt}+\beta_{8} \mathrm{WHEAT}_{\mathrm{t}}+\epsilon_{\mathrm{t}} \\
& \mathrm{WHEAT}_{\mathrm{t}}=\alpha_{9}+\beta_{1} \mathrm{MPR}_{\mathrm{t}}+\beta_{2} \mathrm{HSD}_{\mathrm{t}}+\beta_{3} \mathrm{KO}_{\mathrm{t}}+\beta_{4} \mathrm{PS}_{\mathrm{t}}+\beta_{5} \mathrm{RB}_{\mathrm{t}}+\beta_{6} \mathrm{RBB}_{\mathrm{t}}+\beta_{7} \mathrm{RBSt}+\beta_{8} \mathrm{WHEAT}_{\mathrm{t}}+\epsilon_{\mathrm{t}}
\end{aligned}
$$

Where as MPR is the monetary policy rate, $t$ is the time variate, GT24 is (Gold Tezabi 24 carat), HSD is (High-speed diesel), KO is (Kerosene oil), PS is (Petrol super), RB is (Rice basmati), RBB is (Rice basmati broken), RI is (Rice Irri-6 Wheat), $e$ is represented by error term (Residuals). 


\section{Results \& Discussion}

In Table 1, the descriptive analysis suggests that the correlation among different variables and time series quantitative data assess. Table 1 consists of Mean, Median, mode show overall on the average range and standard deviation estimates dispersion in given data set as well as maximum (high value) and minimum (low value) is also part of the study. It also associates the relationship between variables that depicts values significant or insignificant. The result shows that the mean price of the sample period of Gold Tezabi 24CT10 GM is 39252.44 for the last eight years approximately.

On the contrary, Jarque-Bera (P value) is 0.0247 which means insignificant because of its value is less than 0.05 . Hence the data is not normally distributed. The result represents high-speed Diesel (HSD LTR) 87.87 on average in the data set. However, Jarque-Bera (P value) is 0.0287 that shows data is insignificant due to p-value below 0.05 . So it is not normally distributed.

Table 1. Descriptive Analysis

\begin{tabular}{lcccccccccc}
\hline & MPR & GT24 & HSD & KO & PS & RB & RBB & RBS & RI & WHEAT \\
\hline Mean & 0.104 & 39252.44 & 87.8768 & 94.4066 & 83.2902 & 77.5057 & 59.0990 & 108.447 & 43.6729 & 299.641 \\
Median & 0.1013 & 40995.35 & 83.7900 & 90.8400 & 77.7900 & 75.4050 & 59.6400 & 111.695 & 44.8950 & 281.825 \\
Max. & 0.1401 & 53870.28 & 116.950 & 127.530 & 113.260 & 96.8800 & 73.7600 & 140.530 & 51.3700 & 403.940 \\
Min. & 0.0582 & 19702.29 & 56.5200 & 62.5700 & 57.3500 & 57.9300 & 41.3200 & 78.1400 & 32.5100 & 217.040 \\
Std.Dev. & 0.0249 & 9143.54 & 18.3849 & 19.8906 & 17.1772 & 12.0091 & 10.7239 & 20.3896 & 5.91247 & 47.5142 \\
Skewnes & -0.4446 & -0.62837 & 0.02367 & 0.10853 & 0.25161 & 0.09486 & -0.2352 & 0.07389 & -0.5271 & 0.26056 \\
Kurtosis & 2.03053 & 2.556419 & 1.69582 & 1.73192 & 1.72118 & 1.76715 & 1.72001 & 1.60981 & 1.91497 & 1.84022 \\
JB Value & 0.02717 & 0.024715 & 0.02878 & 0.03180 & 0.01955 & 0.03911 & 0.02077 & 0.01705 & 0.0085 & 0.03446 \\
\hline
\end{tabular}

Table 1 shows that Kerosene oil (KO LTR) mean price per liter 94.40 on average in data set for the last many years, and the standard deviation is 19.89. Table 1 depicts that Petrol super (PS LTR) mean price is 83.29, and Jarque-Bera is 0.0195 . In Table 1 illustrate that Rice Basmati (RB kg) mean price is 77.50 and Jarque-Bera is 0.0391 . From Table 1, it suggests that Rice Basmati Super Quality (RBS kg) mean average price is 108.44 for it and the p-value is 0.0170 . Table 1 also shows that Wheat $(\mathrm{kg})$ means the price is 299.64 and Jarque-Bera p-value is 0.0344 .

Firstly, all variables checked whether stationary is there or not. The result of the Augmented Dickey-Fuller (ADF) test shows that all variables have unit roots in the level form, but there are no unit roots at first difference. Table 2 shows the result of a stationary test. Gold Tezabi turn into stationary at first difference level and zero difference level is not stationary because $\mathrm{p}$-value is more than five percentages above the significance level. The rest of other variables have the same problem of stationary in overall variables. Therefore, we obtain the first difference. Then the problem of stationary is removed from variables. The Augmented Dickey-Fuller test examines the outcomes in order to meet the prerequisite of the conceptual 
framework. It is employed Vector Auto-Regression Model for choosing a minimum number of lags in order to satisfy no existence of autocorrelation and heterocedasticity.

Table 2. Augmented Dickey-Fuller (ADF) Test

\begin{tabular}{ccc}
\hline Series & Level & First Difference \\
\hline TB6 & 0.9447 & 0,0000 \\
GT24 & 0.2640 & 0,0000 \\
HSD & 0.5906 & 0,0000 \\
KO & 0.5790 & 0,0000 \\
PS & 0.5230 & 0,0000 \\
RB & 0.7140 & 0,0000 \\
RBB & 0.7379 & 0,0002 \\
RBS & 0.9810 & 0,0004 \\
RI & 0.6245 & 0,0001 \\
Wheat & 0.4014 & 0,0000
\end{tabular}

The impulse response function is used to evaluate and depicts that impact of in MPR (TB6) on rice price sustains 5-6 months whereas it is to eliminate in the long run. In other words, we can say that there is a short-term relationship between variable rather than a longrun perspective. Therefore, consumers will be affected negatively due to the increase in the price of rice. Figure 1 shows that there is the impact of in MPR (TB6) on Gold Tezabi (24) on short term perspective whereas long term because the graph is more or less parallel to $\mathrm{x}$-axis which suggests that effect of interest rate is removed but increase in interest rate lead to shrinking goldsmith purchasing power 5-6 months. In a nutshell, the interest rate affects yellow metal greatly in the period of the short run.

Besides that, Figure 1 explains that the response of an MPR (TB6) shocks on Highspeed diesel (HSD) is negative for 4-5 months because interest rate increases HSD get a little impact on the short term rather than the long term as prices of rice get much fluctuation for a certain period in months. It can say that in MPR (TB6) on Kerosene oil do have an impact on 5-6 months in short-term as the graph does not show a long-run effect on KO. So we can predict that prices of kerosene oil can fluctuate in short-term relatively than long-term.

Figure 1 also shows that in MPR (TB6) on Petrol super has a negative impact because it reminds not positive 7-8 months respectively and its' impact has long run rather than short-run perspective. Besides that, Figure 1 explores that MPR (TB6) on rice basmati super; continue 5-6 months as compared to the long run. It can examine that there is a little impact on these variables along a period of ten years. So, consumers' purchasing power gets much influence on it and has to stay away from the market. 
Figure 1. Impulse Response Function Result

Response to Cholesky One S.D. Innovations \pm 2 S.E. Response to Cholesky One S.D. Innovations \pm 2 S.E.
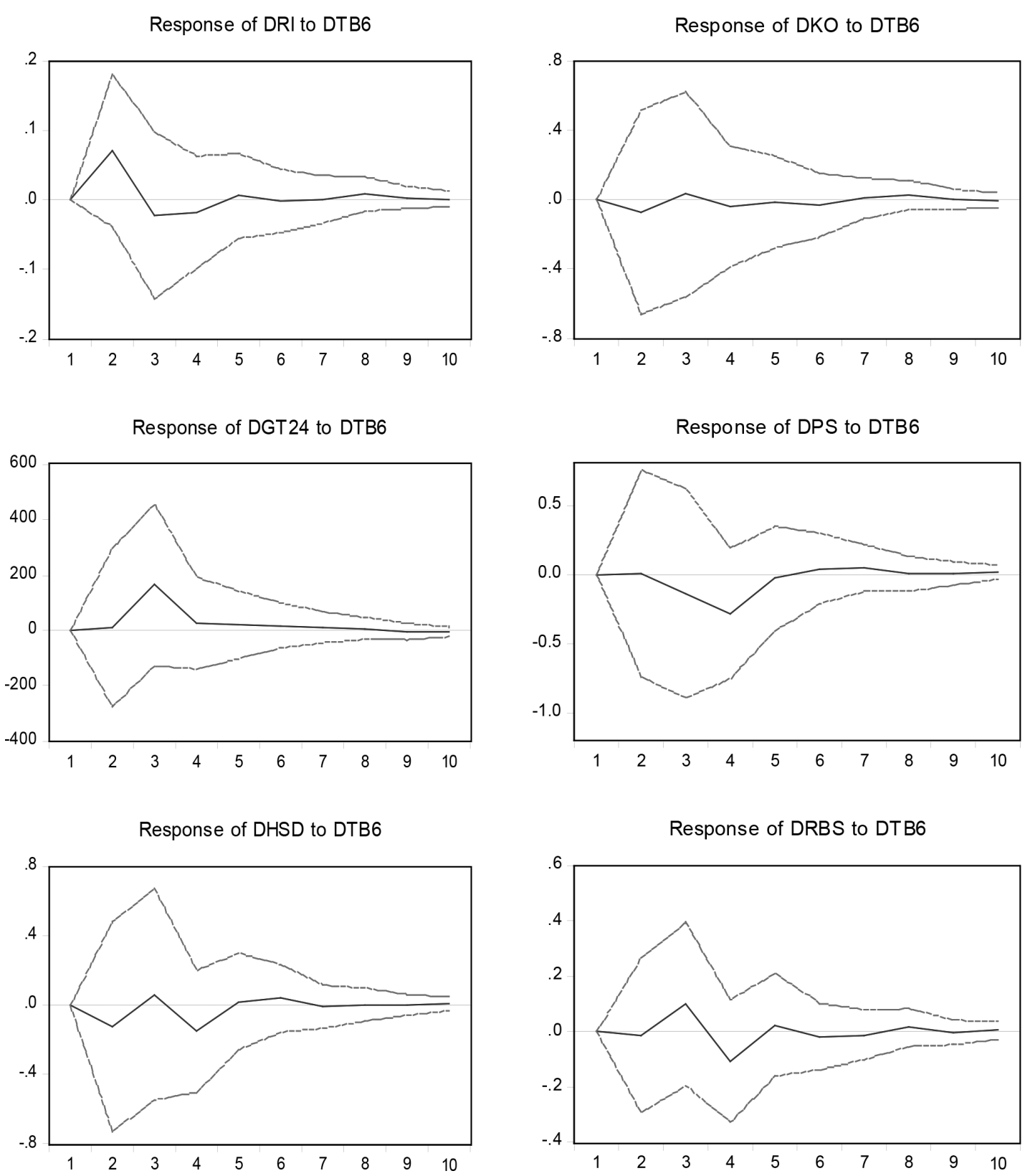
Figure 2. The Result of Impulse Response Function

Response to Cholesky One S.D. Innovations \pm 2 S.E.

Response of DRB to DTB6

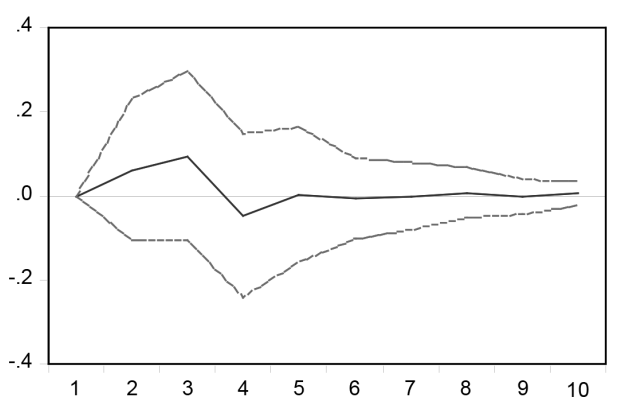

Response of DRRB to DTB6

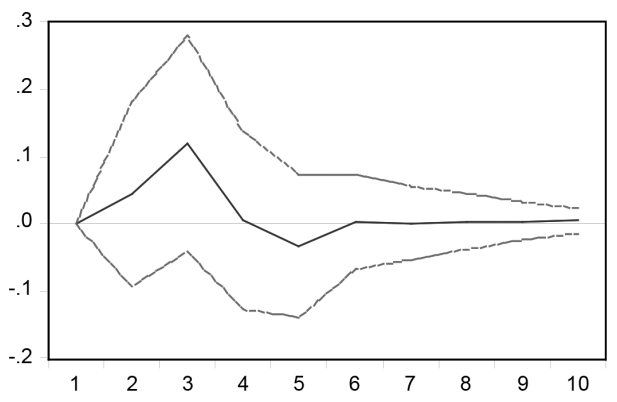

Response of DWHEAT to DTB6

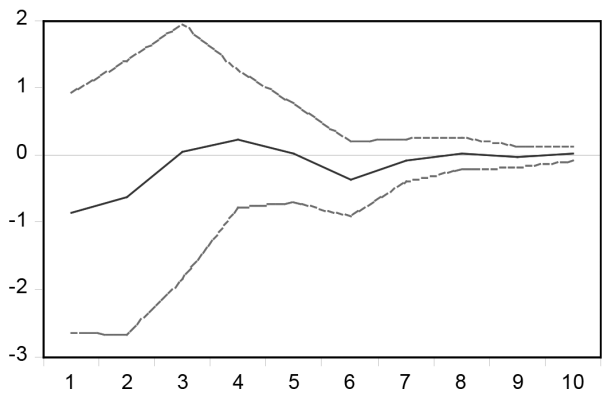

Figure 2 explores that MPR (TB6) on rice basmati broken and continues 5-6 months as compared to the long run. There is a little impact on these variables along a period of ten years. In order words, consumers' purchasing power get much influence on it and have to stay away from the market. The response of MPR (TB6) shocks on Wheat is negative for 7-8 months because interest rate increases; Wheat gets much impact on the short term. As prices of wheat play an essential role to consumers and it is an essential commodity that has a significant effect on average people in the case of Pakistan.

There is multi-analysis of different variables in the following figures which show positive and negative impact in the short run and long run. The effect of the impulse of interest rate is going to affect Gold Tezabi (GT24) prices for 5-6 months, and there is a little impact on the long-run perspective. The effect of interest rate is going to affect High-speed diesel (HSD) not much in the short term. Whereas, long-term values are more or less parallel to the $\mathrm{x}$-axis, which suggests that, the effect of interest rate removed. The effect of interest rate on Kerosene 
oil (KO) does have an impact on 5-6 months in short-term, as the values do not show a longrun effect on KO. So we can predict that prices of kerosene oil can fluctuate in the short-term rather than long-term. The effect of the impulse of interest rate is going to affect a little on Petrol super price.

Bodenstein et al. (2008) conclude that there is an adverse energy supply shock that implies a rise in core inflation. Wang et al. (2014) indicate that the responses of agricultural commodity prices to oil price changes depend significantly on whether they cause oil supply shocks, aggregate demand shocks or other oil-specific shocks mainly driven by precautionary demand. Ahmadi et al. (2016) find that based on impulse response functions, the response of volatility of each commodity to an oil price shock differs significantly depending on the underlying cause of the shock. Rafiq \& Bloch (2016) explain that the long-run positive impacts of oil prices found for 20 commodities and short-run negative impacts for 13 commodity prices.

The empirical result in the appendix (Table A until Table G) is showing results of vector autoregression model describing with Granger Casualty test that where variables are dependent on each other and impact can be checked reciprocally. There is no Granger cause MPR on High-Speed Diesel (HSD) 0.043 and Kerosene Oil (KO) 0.0085 that shows significant Bi-Directional effect. Hence there is a significant relationship between HSP \& KO. Furthermore, rest of remaining variables -such as Gold Tezabi, Petrol Super, Rice Basmati, Rice Basmati Broken, Rice Basmati-irri and Wheat- p-values are 0.060, 0.582, 0.072, 0.151, 0.286 and 0.102 respectively. So, here is no Granger cause Bi-directional impact on the variables. The response of monetary policy shocks on commodity price shows overall progress of variables in order to examine p-value of whole Granger Causality Test show 0.0007, having Bi-Directional significant relationship among one another.

Gubler \& Hetweck (2013) shows that commodity price shocks are a significant driving force of macroeconomic fluctuations. Chambers \& Just (1982) shows that tight monetary policy will lower prices and increase demand for domestic agriculture. Belke et al., (2010), Browne \& Cronin, 2010) find that different price elasticity in commodity and consumer goods market can explain the recently observed overshooting of the commodity over consumer prices. The agricultural spot price can fall by exhibiting a wrong adjustment at the instant of the announcement of the increase in the money supply under certain conditions (Tai et al., 2014).

Hammoudeh et al. (2015) conclude that policymakers should recognize the source of sector inflation before taking monetary policy. The appropriate response to commodity induced exogenous shocks is to target CPI inflation (Hove et al., 2015). Countries with more independent central banks and higher governance scores seem to have contained the impact of the commodity price shocks better (Gelos \& Ustugova, 2017).

\section{Conclusion}

It is to summarize our findings that there is an implicit effect of monetary policy on commodity prices based on the short-term interest rate in our economy in the case of Pakistan under assessment in our empirical study. Higher volatility in interest rate presents a higher 
impact on commodity prices in short-run. It believes that high prices of commodities always affect ordinary people more than rich people because ordinary people are not able to escape themselves against fluctuation in costs and cannot face risks.

The government is keen to implement low prices of rice and wheat and reduce the burden on ordinary people, which central bank has pointed out in its statement on financial policy. The central banks should announce and communicate monetary policy related to underlying inflation than a headline in economics.

\section{References}

Ahmadi, M., Behmiri, N. B., \& Manera, M. (2016). How is Volatility in Commodity Market Linked to Oil Price Shocks? Energy Economics, 59, 11-23. https://doi.org/10.1016/j. eneco.2016.07.006

Anzuini, A., Lombardi, M. J., \& Pagano, P. (2013). The Impact of Monetary Policy Shocks on Commodity Prices. International Journal of Central Banking, 9(3), 125-150.

Belke, A., Bordon, I. G., \& Hendricks, T. W. (2010). Global Liquidity and Commodity Prices-A Cointegrated VAR Approach for OECD Countries. Applied Financial Economics, 20(3), 227-242.

Bodenstein, M., Erceg, C. J., \& Guerrieri, L. (2008). Optimal Monetary Policy with Distinct Core and Headline Inflation Rates. Journal of Monetary Economics, 55(S1), S18-S33.

Browne, F., \& Cronin, D. (2010). Commodity Prices, Money and Inflation. Journal of Economics and Business, 62(4), 331-345.

Chambers, R. G., \& Just, R. E. (1982). An Investigation of The Effect of Monetary Factors on Agriculture. Journal of Monetary Economics, 9(2), 235-247. https://doi. org/10.1016/0304-3932(82)90044-7

Cody, B. J., \& Mills, L. O. (1991). The Role of Commodity Prices in Formulating Monetary Policy. The Review of Economics and Statistics, 73, 358-365.

Devereux, M. B., Lane, P. R., \& Xu, J. (2006). Exchange Rates and Monetary Policy in Emerging Market Economies. The Economic Journal, 116(511), 478-506. https://doi. org/10.1111/j.1468-0297.2006.01089.x

Frankel, J. A. (2006). The Effect of Monetary Policy on Real Commodity Prices. Working Paper No. W12713. National Buerau of Economic Research.

Gali, J., \& Monacelli, T. (2005). Monetary Policy and Exchange Rate Volatility in a Small Open Economy. The Review of Economic Studies, 72(3), 707-734.

Garner, C. A. (1985). Commodity Prices and Monetary Policy Reform. Economic Review, 70(2), 7-22.

Gelos, G., \& Ustugova, Y. (2017). Inflation Responses to Commodity price shocks -How and Why do Countries Differ? Journal of International Money and Finance, 72, 28-47. https://doi.org/10.1016/j.jimonfin.2016.10.001

Gubler, M., \& Hetweck, M. S. (2013). Commodity Price Shocks and the Business Cycle: 
Structural Evidence for the US. Journal of International Money and Finance, 37(324352). https://doi.org/10.1016/j.jimonfin.2013.06.012

Hammoudeh, S., Nguyen, D. K., \& Sousa, R. M. (2015). US Monetary Policy and Sectoral Commodity Prices. Journal of International Money and Finance, 57, 61-85. https://doi. org/10.1016/j.jimonfin.2015.06.003

Hove, S., Mama, A. T., \& Tchana, F. T. (2015). Monetary Policy and Commodity Terms of Trade Shocks in Emerging Market Economies. Economic Modelling, 49, 53-71. https:// doi.org/10.1016/j.econmod.2015.03.012

Lapp, J. S. (1990). Relative Agricultural Prices and Monetary Policy. American Journal of Agricultural Economics, 72(3), 622-630.

Laxton, D., \& Pesenti, P. (2003). Monetary Rules for Small, Open, Emerging Economies. Journal of Monetary Economics, 50(5), 1109-1146.

Lovcha, Y., \& Perez-Laborda, A. (2018). Monetary Policy Shocks, Inflation Persistence, and Long Memory. Journal of Macroeconomics, 55, 117-127. https://doi.org/10.1016/j. jmacro.2017.10.006

Pain, N., Koske, I., \& Sollie, M. (2006). Globalisation and Inflation in the OECD Countries. OECD Economics Department Working Papers No. 524. https://doi. org/10.1787/377011785643

Parrado, E. A., Flippen, C. A., \& McQuinston, C. (2004). Use of Commercial Sex Workers Among Hispanic Migrants in North Carolina: Implications for The Spread of HIV. Perspectives on Sexual and Reproductive Health, 36(4), 150-156.

Pindyck, R. S., \& Rotemberg, J. J. (1993). The co-movement of stock prices. The Quarterly Journal of Economics, 108(4), 1073-1104.

Rafiq, S., \& Bloch, H. (2016). Explaining Commodity Prices Through Asymmetric Oil Shocks: Evidence from Nonlinear Models. Resources Policy, 50, 34-48. https://doi. org/10.1016/j.resourpol. 2016.08.005

Scrimgeour, D. (2015). Commodity Price Responses to Monetary Policy Surprises. American Journal of Agricultural, 97(1), 88-102.

Tai, M. Y., Chao, C. C., Hu, S. W., Lai, C. C., \& Wang, V. (2014). Monetary Policy and Price Dynamics in a Commodity Futures Market. International Review of Economics and Finance, 29, 372-379. https://doi.org/10.1016/j.iref.2013.06.007

Wang, Y., Wu, C., \& Yang, L. (2014). Oil Price Shocks and Agricultural Commodity Prices. Energy Economics, 44, 22-35. https://doi.org/10.1016/j.eneco.2014.03.016

Wynne, M. A., \& Kersting, E. K. (2007). Openness and Inflation. Working Paper Federal Reserve Bank of Dallas. 


\section{Appendix}

Vector Auto-Regression Model (Granger Causality Test)

Table A. Dependent variable: DMPR

\begin{tabular}{cccc}
\hline Excluded & Chi-sq & Df & Prob. \\
\hline DRI & 2.500938 & 2 & 0.2864 \\
DGT24 & 5.604372 & 2 & 0.0607 \\
DHSD & 6.292309 & 2 & 0.0430 \\
DKO & 9.538159 & 2 & 0.0085 \\
DPS & 1.080076 & 2 & 0.5827 \\
DRBS & 0.374361 & 2 & 0.8293 \\
DRB & 5.258703 & 2 & 0.0721 \\
DRRB & 3.780460 & 2 & 0.1510 \\
DWHEAT & 4.561621 & 2 & 0.1022 \\
All & 43.49684 & 18 & 0.0007 \\
\hline
\end{tabular}

Table B. Dependent variable: DGT24

\begin{tabular}{cccl}
\hline Excluded & Chi-sq & Df & Prob. \\
\hline DRI & 5.394572 & 2 & 0.0674 \\
DHSD & 5.477014 & 2 & 0.0647 \\
DKO & 3.145479 & 2 & 0.2075 \\
DPS & 2.108730 & 2 & 0.3484 \\
DRBS & 4.362179 & 2 & 0.1129 \\
DRB & 1.289252 & 2 & 0.5249 \\
DRRB & 2.335219 & 2 & 0.3111 \\
DTB6 & 1.051257 & 2 & 0.5912 \\
DWHEAT & 0.818773 & 2 & 0.6641 \\
All & 20.83812 & 18 & 0.2877 \\
\hline
\end{tabular}

Table C Dependent variable: DHSD

\begin{tabular}{cccl}
\hline Excluded & Chi-sq & Df & Prob. \\
\hline DRI & 3.695533 & 2 & 0.1576 \\
DGT24 & 0.922025 & 2 & 0.6306 \\
DKO & 5.299726 & 2 & 0.0707 \\
DPS & 1.086716 & 2 & 0.5808 \\
DRBS & 2.966694 & 2 & 0.2269 \\
DRB & 2.728286 & 2 & 0.2556 \\
DRRB & 1.458419 & 2 & 0.4823 \\
DTB6 & 0.273735 & 2 & 0.8721 \\
DWHEAT & 1.054467 & 2 & 0.5902 \\
All & 18.85199 & 18 & 0.4010 \\
\hline
\end{tabular}


Table D. Dependent variable: DKO

\begin{tabular}{cccl}
\hline Excluded & Chi-sq & Df & Prob. \\
\hline DRI & 1.771122 & 2 & 0.4125 \\
DGT24 & 0.510491 & 2 & 0.7747 \\
DHSD & 2.606993 & 2 & 0.2716 \\
DPS & 0.302668 & 2 & 0.8596 \\
DRBS & 2.976748 & 2 & 0.2257 \\
DRB & 2.472989 & 2 & 0.2904 \\
DRRB & 1.149188 & 2 & 0.5629 \\
DTB6 & 0.163862 & 2 & 0.9213 \\
DWHEAT & 0.495493 & 2 & 0.7806 \\
All & 14.86745 & 18 & 0.6710 \\
\hline
\end{tabular}

Table E. Dependent variable: DRB

\begin{tabular}{|c|c|c|c|}
\hline Excluded & Chi-sq & Df & Prob. \\
\hline DRI & 5.794763 & 2 & 0.0552 \\
\hline DGT24 & 0.006757 & 2 & 0.9966 \\
\hline DHSD & 1.080517 & 2 & 0.5826 \\
\hline DKO & 4.462865 & 2 & 0.1074 \\
\hline DPS & 9.719766 & 2 & 0.0078 \\
\hline DRBS & 22.29900 & 2 & 0.0000 \\
\hline DRRB & 15.68095 & 2 & 0.0004 \\
\hline DTB6 & 1.050996 & 2 & 0.5913 \\
\hline DWHEAT & 2.329010 & 2 & 0.3121 \\
\hline All & 85.57874 & 18 & 0.0000 \\
\hline Excluded & Chi-sq & df & Prob. \\
\hline DRI & 7.658038 & 2 & 0.0217 \\
\hline DGT24 & 1.540963 & 2 & 0.4628 \\
\hline DHSD & 0.040439 & 2 & 0.9800 \\
\hline DKO & 0.772211 & 2 & 0.6797 \\
\hline DPS & 1.397111 & 2 & 0.4973 \\
\hline DRBS & 11.93786 & 2 & 0.0026 \\
\hline DRB & 6.277442 & 2 & 0.0433 \\
\hline DTB6 & 2.594900 & 2 & 0.2732 \\
\hline DWHEAT & 4.978148 & 2 & 0.0830 \\
\hline All & 46.67169 & 18 & 0.0002 \\
\hline
\end{tabular}


Table G. Dependent variable: WHEAT

\begin{tabular}{cccc}
\hline Excluded & Chi-sq & df & Prob. \\
\hline DRI & 1.688830 & 2 & 0.4298 \\
DGT24 & 0.339087 & 2 & 0.8440 \\
DHSD & 0.001135 & 2 & 0.9994 \\
DKO & 0.512714 & 2 & 0.7739 \\
DPS & 0.594960 & 2 & 0.7427 \\
DRBS & 0.384481 & 2 & 0.8251 \\
DRB & 2.323671 & 2 & 0.3129 \\
DRRB & 1.578211 & 2 & 0.4543 \\
DTB6 & 0.285999 & 2 & 0.8668 \\
All & 11.27907 & 18 & 0.8821 \\
\hline
\end{tabular}

